\title{
Scandinavian Object Shift: The Interface between Syntax, Phonology, and Information Structure
}

\author{
MAYUMI HOSONO \\ Leiden University ${ }^{1}$
}

\section{Introduction}

In the Scandinavian languages, a full NP object follows a sentential adverb like the negation in the unmarked case (1a), whereas a weak pronominal object can move across such a sentential adverb (1b). ${ }^{2}$ This movement phenomenon is called Object Shift OS (Holmberg 1986, 1999). ${ }^{3}$

$$
\begin{aligned}
& \text { a. Jag kysste inte Marit. } \\
& \text { I kissed not Marit } \\
& \text { 'I didn't kiss Marit.' }
\end{aligned}
$$

b. Jag målade den inte.

I painted it not

'I didn't paint it.'

OS in the Scandinavian languages is dependent on verb movement (Holmberg's Generalization, Holmberg 1986). That is, in simple tense forms (2a), the main verb moves to the second position; the object pronoun can move too. OS is obligatory in some Scandinavian varieties, but optional in others. In complex tense forms and embedded clauses, however, the main verb does not move. In complex tense forms (2b), the main verb does not move due to the presence of the Aux; the object pronoun cannot move and follow the Aux. In embedded clauses (2c), main verb movement does not occur; the object pronoun cannot move and follow the embedded subject.

$$
\begin{aligned}
& \text { a. Jag målade }<\mathrm{OK} \text { den }>\text { inte målade }<\mathrm{OK}_{\mathrm{den}}>\text {. } \\
& \text { I painted it not it } \\
& \text { 'I didn't paint it' }
\end{aligned}
$$

[Swe.]

1 This work is to dedicate to the memory of Gösta Bruce. Without his great interest in and support for this work during my stay in Lund, autumn 2009, it could not appear. Many thanks to Vincent van Heuven, Anders Holmberg and Johan Rooryck for their invaluable advice, suggestions, help and support for this thesis work. Thanks also to Line Mikkelsen for her long-term interest in my work on Scandinavian Objest Shift. I also would like to thank the audience of BLS 40 for their helpful comments. I take all responsibility for any errors.

2 Abbreviations throughout this paper: Foc - a focus; H - high; L - low; Subj - a subject; S.Adv - a sentential adverb; Aux - an auxiliary verb; $\mathrm{V}_{\text {main }}$ - a main verb in a main clause; $\mathrm{V}_{\text {part }}$ - a past participle; $\mathrm{V}_{\mathrm{emb}}$ - a main verb in an embedded clause; Obj $\mathrm{NP}_{\mathrm{NP}}$ - a full NP object; Obj $\mathrm{j}_{\text {ro }}$ - an object pronoun; $\mathrm{Obj}_{\mathrm{DAT}}$ - a dative object; $\mathrm{Obj}_{\mathrm{ACC}}$ - an accusative (i.e. direct) object; Expl - an expletive; Rel.pro - a relative pronoun.

${ }^{3}$ In this work, the terminology Object Shift refers to weak pronoun shift only. In the discussions below, I deal with only unmarked cases. 
b. Jag har $<*$ den $>$ inte målat $<\mathrm{OK}_{\mathrm{den}}>$.

I have it not painted it

'I haven't painted it.'

c. Jag sa att jag $<*$ honom $>$ inte målade $<{ }^{\mathrm{OK}}$ honom $>$.

I said that I him not portrayed him

'I said that I didn't portray him.'

No movement phenomenon other than OS in which movement of a sentential element is dependent on that of another sentential element has been found. Due to this property, OS has long been one of the most controversial issues in generative syntax (Diesing 1992, 1997; Holmberg and Platzack 1995; Holmberg 1999; Chomsky 2001; Sells 2001; Vikner 2001; Josefsson 2003; Fox and Pesetsky 2005; Erteschik-Shir 2005a,b; Broekhuis 2008; Mikkelsen 2011; among others).

There is much literature on the intonational properties of the Scandinavian languages (Bruce 1977, 1999, 2005, 2007, Bruce and Gårding 1978, Gårding 1998 for Swedish; Kristoffersen 2000, 2007 for Norwegian; Grønnum 1998, Basbøll 2005 for Danish; Árnason 1999, 2011, Gussmann 2002, Dehé 2010 for Icelandic; Árnason 1999, 2011 for Faroese; Kristoffersen 2008 for Övdalian). In this paper, I show, with experimental and statistical data collected from the Scandinavian varieties investigated, that the OS construction such as simple tense forms (2a) has intonational properties different from the non-OS construction such as complex tense forms and embedded clauses (2b-c). That is, downstep (cf. Gussenhoven 2004) occurs in the former but does not occur in the latter. I also present a new system that accounts for not only the facts on OS but also the interaction between the grammatical components, syntax, phonology and information structure.

This paper is organized as follows. Section 2 introduces the Swedish intonational system (Bruce 1977) and presents a prediction on the intonational properties of Swedish OS on the basis of it. Section 3 introduces an experiment to observe the intonational properties of the constructions relevant to Swedish OS and the result. A cross-Scandinavian statistical data is also presented. Section 4 presents a new system that accounts for not only the facts on OS but also the interaction between the grammatical components. Section 5 briefly concludes this paper.

\section{The Swedish Intonational System}

In Swedish, the focus of a sentence is realized by a focal H contour, which is added after the pitch gesture of the main syllable of a focused word (Bruce 1977). In (3), the main verb lämna is (contrastively) focused. A focal accent is located on the first syllable läm- of that main verb. ${ }^{4}$ The focal $\mathrm{H}$ contour occurs immediately after the pitch gesture of that accented syllable. The

${ }^{4}$ Braces indicate the range of the pitch gesture of a relevant accented syllable, i.e. the range of $\mathrm{H}^{*} \mathrm{~L}$ from the $\mathrm{H}$ on which the accent occurs to the following $\mathrm{L}$, here. 
focal $\mathrm{H}$ contains an unaccented quantifier nåra and also the first syllable of an adjective långa, i.e. lann-, the next accentable syllable after the main verb. The pitch peak occurs on that first syllable of the adjective. The pitch then falls on that adjective and continues to be low until the end of the sentence.

(3) Man vill LÄMNA några långa nunnor.

[Swe.] man wants leave some long nuns

'One wants to leave some tall nuns.'

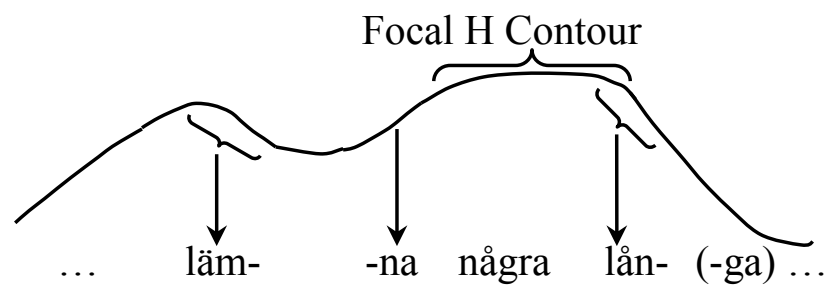

(Bruce 1977:42, Fig. 5)

A prediction on the intonational properties of the OS construction is illustrated in (4). In the unmarked case of the OS construction, the focus of a sentence is carried by a main verb, i.e. målade below; a focal accent occurs on the first syllable må- of that main verb. The focal $\mathrm{H}$ contour should occur immediately after that accented first syllable. ${ }^{5,6}$ The focal $\mathrm{H}$ should contain a shifted object pronoun and also the first syllable of the negation inte, i.e. in-, the next accentable syllable after the main verb. The pitch peak should occur on that first syllable of the negation.
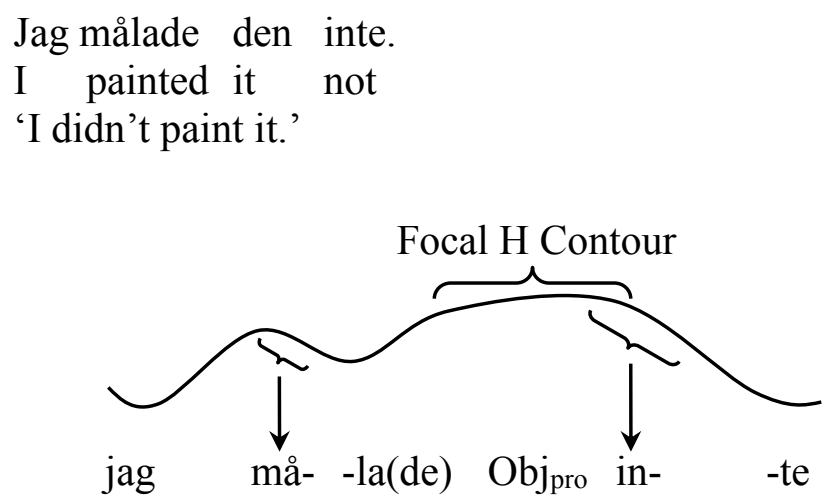

\footnotetext{
5 The final syllable -de of the main verb is dropped in almost all cases. Thus hereafter, I notate it by attaching it in parentheses to the second syllable as in -la(de) in all notations.

${ }^{6}$ One might argue that it should not be predicted from the beginning that the focal $\mathrm{H}$ occurs in the OS construction: due to its given status, the main verb would only keep an (inherent) word accent. However, a focal H should occur in any sentence for an information-structural reason: a sentence must have one and only one focus (Lambrecht 1994). The focal $\mathrm{H}$ in fact occurs even in an all-new sentence that does not contain an 'obviously focused' element such as contrastive focus (Bruce 2007). Thanks to Gilbert Ambrazaitis, Merle Horne and Sara Myrberg for the discussion of this point.
} 


\section{The Intonational Properties of (Swedish) Object Shift}

\subsection{Experiment}

I introduce an experiment to observe the intonational properties of the constructions relevant to OS. The same method applies to all the Scandinavian languages/dialects investigated: Swedish (East, West, North, South, Finland Swedish, Dalecarlian, and Övdalian); Norwegian (East and West); Danish (East and South); Icelandic; and Faroese. A test sentence contains either a monosyllabic object pronoun (e.g. den 'it') or a disyllabic object pronoun (e.g. honom 'him').

With the verb meaning 'paint/portray', e.g. (Swe.) måla, which is etymologically shared by all the Scandinavian languages, the test sentences were systematically translated into the Scandinavian varieties investigated aside from minor morphological differences. In this paper, I present data on Swedish OS as a representative of the Scandinavian languages.

On the basis of the literature on information structure (e.g. Lambrecht 1994, Vilkuna 1995, Kiss 1998), appropriate contexts were built with a question and the answer, the latter of which corresponds to each target construction. Specifically, see Appendix: A - polarity-focus of a simple tense form with a monosyllabic object pronoun; B - polarity-focus of a simple tense form with a disyllabic object pronoun; C - Verb Topicalization, a contrastive verb-focus construction in which the past participle moves to sentence-initial position and a (disyllabic) object pronoun also moves, which was added due to the theoretical significance related to this construction (Holmberg 1999, Chomsky 2001); D - polarity-focus of a complex tense form with a monosyllabic object pronoun; E - polarity-focus of a complex tense form with a disyllabic object pronoun; $\mathrm{F}$ - contrastive argument-focus of a simple tense form with a focused object pronoun; and $\mathrm{G}$ - argument-focus of an embedded clause. In almost all the Scandinavian varieties, the object pronoun moves in $\mathrm{A}, \mathrm{B}$ and $\mathrm{C}$, and does not move in $\mathrm{D}, \mathrm{E}, \mathrm{F}$ and $\mathrm{G}$, in the unmarked case. In section 3.2, I present the data on simple tense forms, complex tense forms and embedded clauses for the limit of pages. A cross-Scandinavian statistical data of all the constructions is presented in section 3.3.

The test sentences were presented to informants in a five-page booklet, in which the same sentences occurred in a different random order on each page. They read all five pages; consequently, each sentence was recorded five times. The conditions (/instructions) under which they read the test sentences are as follows: i) to understand the contexts of each question-answer pair; ii) to read each question-answer pair in appropriately rapid speech, in such a way as they speak in a real-life conversation; and iii) to read all the test sentences even if they felt some of them to be odd and report their native judgments in a questionnaire. The recordings were made one by one, typically in a small lecture room, by the author herself using a laptop with Praat software (Boersma and Weenink 1996) and a microphone. After informants finished reading one page, they took a short break. This procedure was repeated five times. For the Scandinavian 
varieties that were not recorded by the author herself, informants were asked to record their voice and send the sound file to the author by e-mail attachment. The age of the informants ranges from the $20 \mathrm{es}$ to the $80 \mathrm{es}$. The total number of collected tokens of question-answer pairs amounts to 3200 .

A note on the status of collected data is needed. Depending on the speaker's intention, it is possible to put prominence on any of the sentential constituents. However, informants were asked to understand, e.g. did you paint the wall? - no, I didn't paint it, as polarity-focus, before they read it. As long as the contexts are understood by informants in advance, this paper assumes that informants' reading activity, thus all the question-answer pair tokens collected, represent the unmarked case for each of the informants.

\subsection{Results}

The pitch contours of the OS construction are presented in (5). The pitch peak occurs on the first syllable må- of the main verb målade. The pitch lowers on the shifted object pronoun den. The pitch does not rise again on the first syllable in- of the negation inte. That is, contrary to the prediction illustrated in (4), the fundamental frequency F0 of the first syllable of the negation, i.e. in-, is lower than the F0 of the main syllable of a focused main verb in the OS construction of simple tense forms. This indicates that downstep (cf, Gussenhoven 2004) occurs in the OS construction. ${ }^{7}$

Simple tense forms:

(Målade du väggen? - Nej.) Jag målade den inte.

'(Did you paint the wall?' - No.) I didn't paint it.'

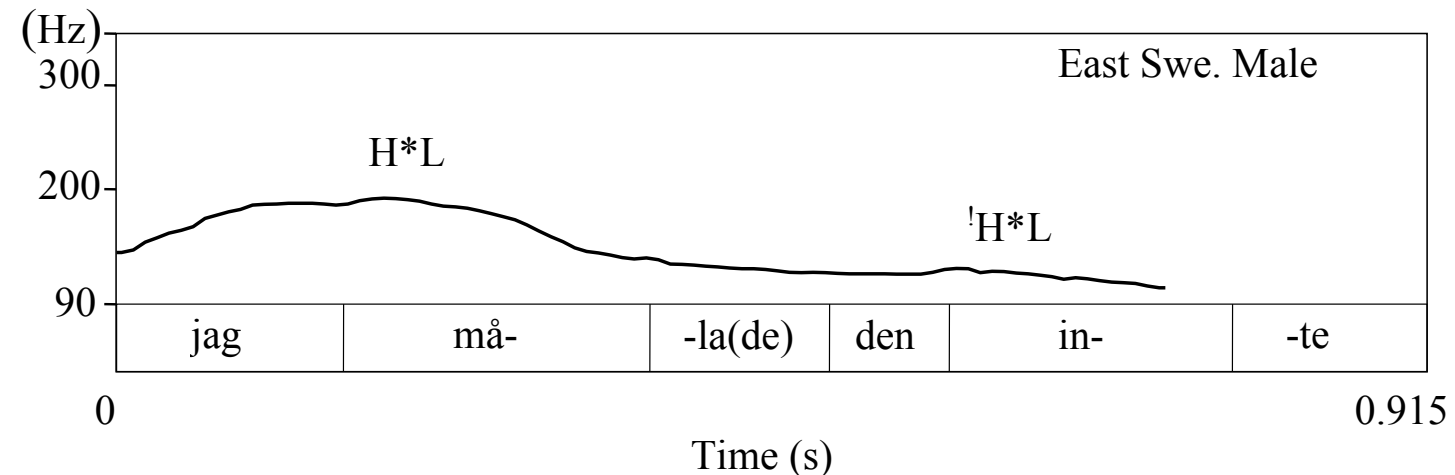

Next, the pitch contours of the non-OS construction are presented in (6-7). In complex tense forms (6), the pitch peak occurs mostly on the first syllable in- of the negation. In embedded clauses (7), the pitch peak occurs on the embedded main verb or on the unshifted object pronoun. (7) illustrates the former case.

${ }^{7}$ In section 3.3, I present a more detailed definition of the term downstep in this paper. 
(6) Complex tense forms:

(Har du målat väggen? - Nej.) Jag har inte målat den.

'(Have you painted the wall? - No.) I haven't painted it.'

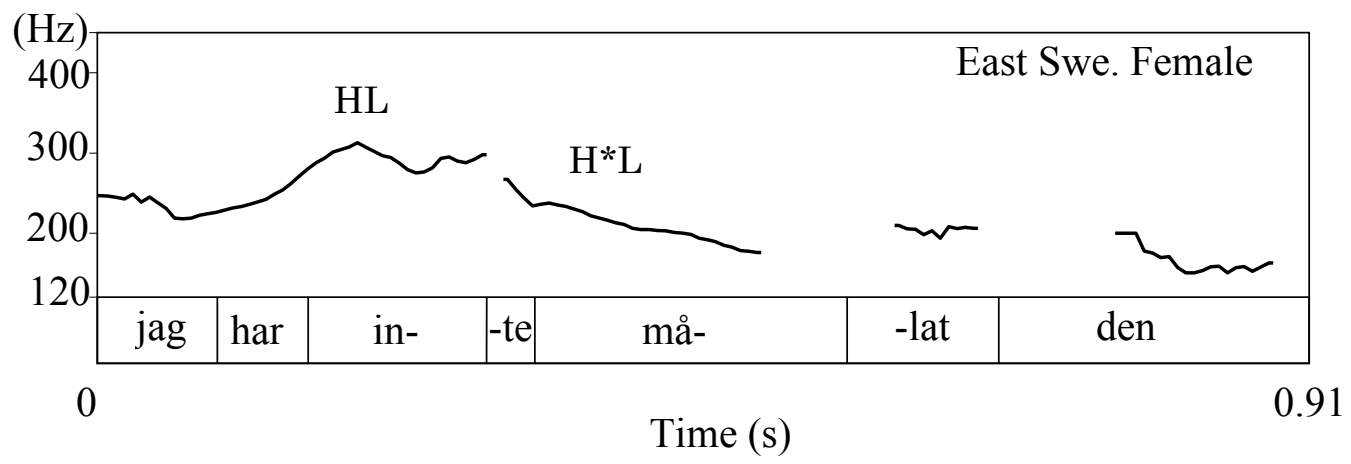

(7) Embedded clauses:

(Vad sa du? -) Jag sa att jag inte målade honom.

'(What did you say? -) I said that I didn't portray him.'

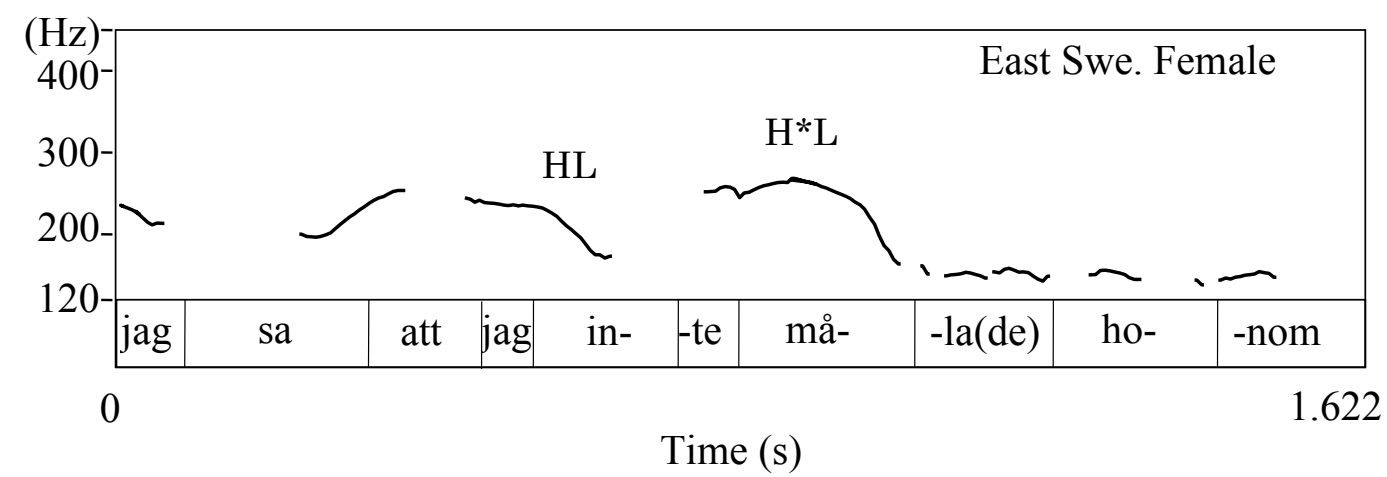

The point here is that the pitch peak occurs on a sentential/clausal element that is located somewhere after the element which an object pronoun cannot follow directly, i.e. on the negation located after the Aux har in the complex tense form (6) and on the main verb (or on the in-situ object pronoun) located after the embedded subject in the embedded clause (7). In both cases, the final pitch peak is most likely to occur on the in-situ main verb. This indicates that downstep does not occur in the non-OS construction.

\subsection{Cross-Scandinavian Statistical Data}

In this section I present a cross-Scandinavian statistical data on downstep (cf. Gussenhoven 2004) 
in the (non-)OS construction. ${ }^{8}$ In this paper, I use the term downstep for the (expected) lowering in pitch between two designated points in time during the course of a spoken utterance. The first key pitch point $\mathrm{P}_{1}$ occurs relatively early in the utterance, whereas the second key pitch point $\mathrm{P}_{2}$ follows towards the end of the utterance. Downstep is defined as the pitch difference between $\mathrm{P}_{1}$ and $\mathrm{P}_{2}$ expressed in semitones (st). I will refer to that pitch difference as the downstep size. When the pitch actually falls, the value of the downstep size will be positive. The higher the value is, the larger the downstep size is. The negative value indicates that downstep does not occur in a sentence: upstep in fact occurs. The lower the value is, the higher the size of upstep/non-downstep is.

For the computation of the downstep size, all the test sentences were articulated by every syllable in advance, and two key pitch points were taken. For the OS construction such as simple tense forms, the first point is on the accented syllable of the main verb, and the second point is on the negation, i.e. the next accentable word after the main verb. The decrement at which the F0 lowers from the main verb to the negation was computed. For the non-OS construction such as complex tense forms and embedded clauses, the first point is on the Aux/embedded subject, which an object pronoun cannot follow directly. The second point was determined by identifying the syllable with the highest pitch value among the syllables that are located after the Aux/embedded subject. The decrement at which the F0 lowers from the Aux/embedded subject to an identified syllable was computed.

A semitone (st), which expresses the downstep size in this paper, is one-twelfth of an octave, which is a doubling of the F0. The interval between any two key pitch points $\mathrm{P}_{1}$ and $\mathrm{P}_{2}$ in Hz was computed by the following formula: ${ }^{9} 12 *\left[\log \left(\mathbf{P}_{1} / \mathbf{P}_{2}\right) / \log (2)\right]$. Since the time interval between $\mathrm{P}_{1}$ and $\mathrm{P}_{2}$ normally does not exceed the duration of one second in my data, I defined a proper instance of downstep as a pitch decrement between $\mathrm{P}_{1}$ and $\mathrm{P}_{2}$ larger than 2 semitones. ${ }^{10}$ This indicates that the difference in semitones between $\mathrm{P}_{1}$ and $\mathrm{P}_{2}$ must be larger than 2 to say that downstep actually occurs in a sentence.

There are two dependent variables which characterize the extent of downstep. One is the incidence of downstep. This variable expresses what percentage of the utterances recorded for a given sentence type in a given Scandinavian variety shows downstep, i.e. the percentage at which the difference in semitones between $\mathrm{P}_{1}$ and $\mathrm{P}_{2}$ is actually larger than 2 . The other variable is the mean size of the pitch decrement between $\mathrm{P}_{1}$ and $\mathrm{P}_{2}$, irrespective of whether the pitch decrement qualifies as a downstep or not (i.e. regardless of whether the semitone between two points is larger than 2 or not). The incidence of downstep and the mean size of the pitch decrement were computed by choosing two representative male and two representative female

${ }^{8}$ I am indebted to Vincent van Heuven for the computation of downstep and the presentation of the statistical data in this section.

9 Without multiplication by 12 , this formula computes the pitch interval in octaves.

10 This estimate is based on the formula, $D=-11 / t+1.5$, to compute the declination $D$ in semitones per second for utterances shorter than 5 seconds, where $t$ is the duration of the utterance ('t Hart, Collier and Cohen, 1990, Rietveld and Van Heuven, 2009). 
speakers in each of the Scandinavian varieties investigated, and processed with the SPSS statistical software.

(8) is a graph of the comparison of the mean downstep size and the actual incidence of downsteps in between the OS construction, A, B and C (upper panel) and all the other construction types (lower panel) in all the Scandinavian languages investigated. In all the Scandinavian varieties in general, the percentage at which downstep actually occurs, i.e. the percentage at which the difference in semitones is actually larger than 2, which is illustrated by light bars, is substantially higher in the OS construction, A, B and C (upper panel) than in the other construction types (lower panel). Regarding the mean downstep size, which is illustrated by dark bars, that of the OS construction has a positive value in almost all the Scandinavian varieties (except in East Danish) as illustrated in the upper panel. The mean downstep size of the other construction types has a negative value in all the varieties as illustrated in the lower panel, which indicates the absence of downstep in the non-OS construction.

(8) Comparison of the mean downstep size (dark bars) and the actual incidence of downsteps (light bars) in between the OS construction (upper panel) and all the other construction types together (lower panel) ${ }^{11}$

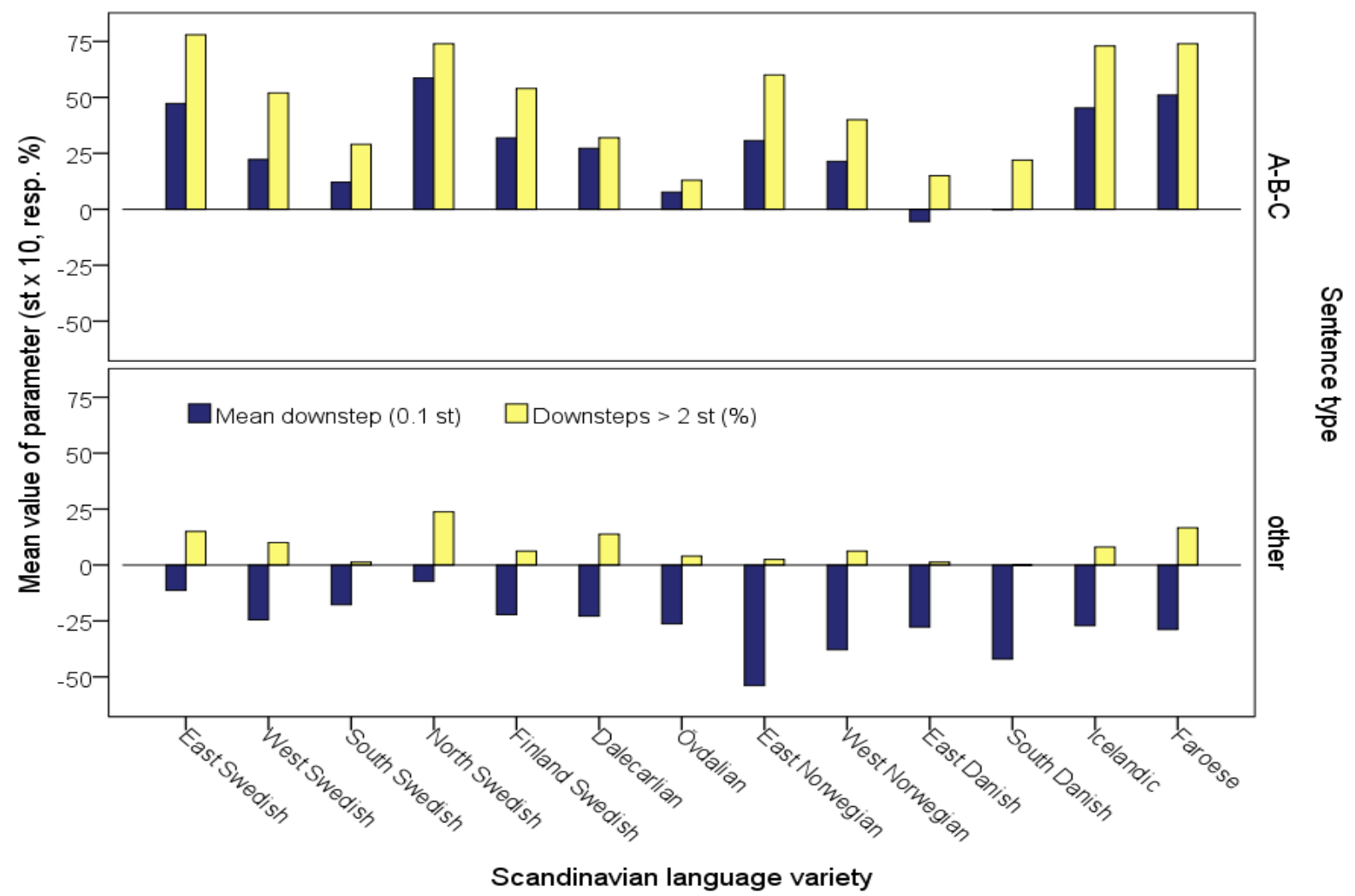

${ }^{11}$ In graph (8) the downstep size is multiplied by a factor 10 in order to obtain bars of approximately the same height as the percentages of downsteps realized (between 0 and 75). 
In sum, downstep is more likely to occur in the OS construction but less likely to occur in the other construction types (in which upstep is likely to occur).

\section{The Interaction between Syntax, Intonation and Information Structure}

I propose a new system that accounts for the facts on OS as well as the interaction between the grammatical components in general. The basic idea is that in theorizing the interaction between syntax, information structure and intonation, only the focal point and the highest pitch peak point need to be taken into account, whereas the locus of an accent is not primary: the highest pitch peak point always points to the focal point on it or quite near it, whereas the stressed syllable of a word is accented regardless of whether that word carries the focus of a sentence or not. The relation between the pitch peak point and the focal point is stated as the following principle:

(9) The highest pitch peak point mostly coincides with the focal point. ${ }^{12}$

There is much literature on information structure (in a wide sense): Mathesius (1929); Halliday (1967); Firbas (1974); Chomsky (1970); Jackendoff (1972); Gundel (1974); Chafe (1976); Kuno (1976); Li and Thompson (1976); Dik (1978); Givón (1979); Selkirk (1984, 1995); Vallduví (1990); Vallduví and Engdahl (1996); Lambrecht (1994); Rizzi (1997); Zubizarreta (1998); Bresnan (2001); Steube (2004, eds.); Hengeveld and Mackenzie (2006); Schwabe and Winkler (2007, eds.); among others. In this work, I define information structure as follows:

\section{(10) Information Structure:}

The discourse concepts that mediate between the grammatical components such as syntax and phonology to express the information flow of a sentence in a language at issue

The basic concept here is the focus, the center of a given discourse, which plays a central role in the system proposed below. ${ }^{13}$ The proposed system has a focal pointer fp, ' indicator of the change in the information flow of a sentence. An illustration is given in (11). The word order goes on from the left to the right. The $\mathrm{fp}$ indicates the location of a focus, Foc. The pitch peak mostly coincides with that focal point. After that pitch peak, downstep occurs in the position(s) following that focal point.

\footnotetext{
12 This principle is compatible with the widely claimed view in the literature: a focused constituent must contain the word most prominent in a sentence. See Chomsky and Halle (1968), Schmerling (1976), Gussenhoven (1984), Selkirk (1984, 1995), Rochemont (1986), Cinque (1993), Zubizarreta (1998), Kahnemuyipour (2009), among others, for the theory of sentence accentuation.

${ }^{13}$ Following Lambrecht (1994), I assume i) that any sentence must have a focus and can have one and only one focus, and ii) that when a phrase is focused, the unaccented word(s) is (are) contained in a focal domain. Thus, in argument-focus, (what do you want? -) I want [a banana], the phrase [a banana] is focused and comprises a focal domain (indicated by brackets) in which the unstressed indefinite article is contained.
} 
(11) The interaction between syntax, intonation and information structure:

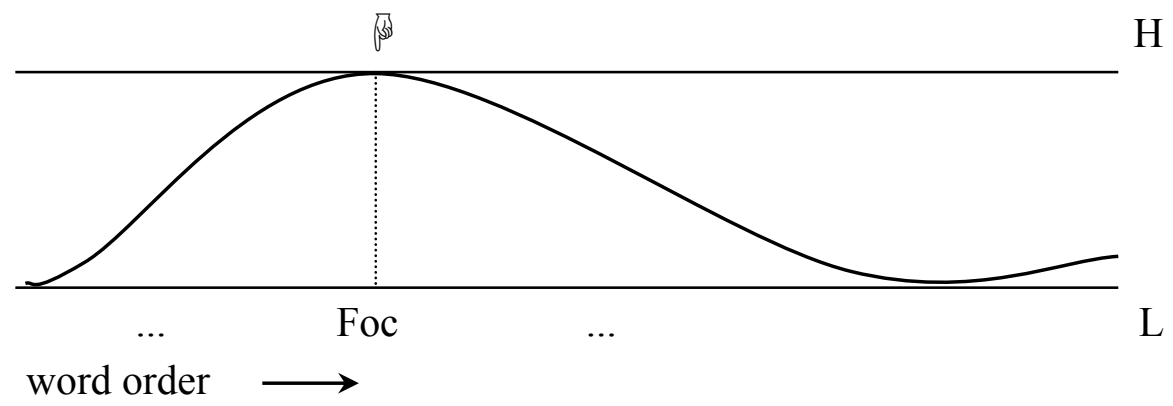

A cross-linguistic prediction from the proposed system is that the farther the fp moves from an unmarked position, the more an unmarked intonation pattern is likely to change, and the more an unmarked syntactic word order is likely to be affected.

Example (12) is an illustration of the unmarked case of SVO languages. The syntactic word order is SVO from the left to the right. It is a standard claim that in transitive constructions, the focus is carried by a (full NP) object in the unmarked case (Gundel 1988). The fp is normally located on the object (NP). The pitch rises towards the object; the pitch peak occurs on one of the phrasal elements that compose the object. After that pitch peak, downstep occurs in the position(s) following that focal point.

The unmarked case of SVO languages:

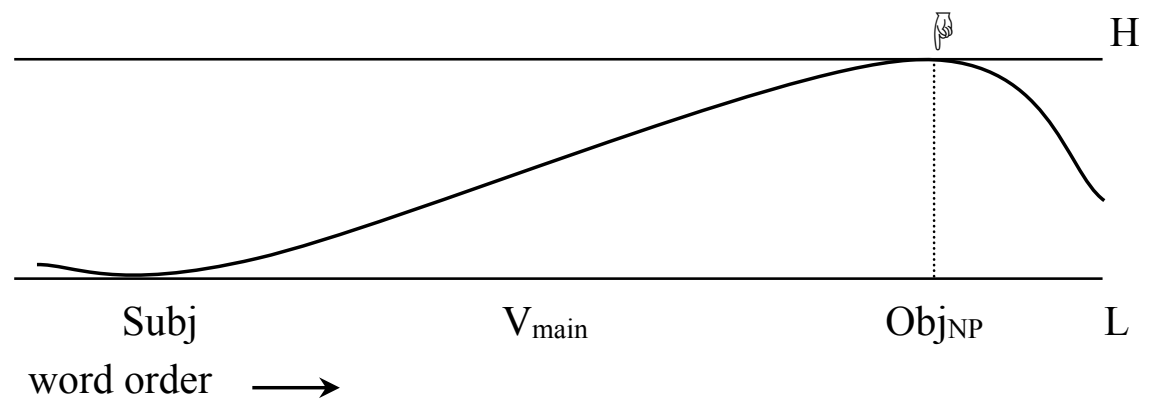

In this language type, the focus of a sentence and the final pitch peak occur near the end of the sentence. Therefore, the prediction is that the farther the fp moves from the unmarked object position to the left, the unmarked intonation pattern is more likely to change; the unmarked syntactic word order is more likely to be affected too. (13) illustrates the interaction between the changes of the focal point, the pitch peak point and the syntactic word order in SVO languages. 
(13) The interaction between the changes of the focal point, the pitch peak point and the syntactic word order in SVO languages:

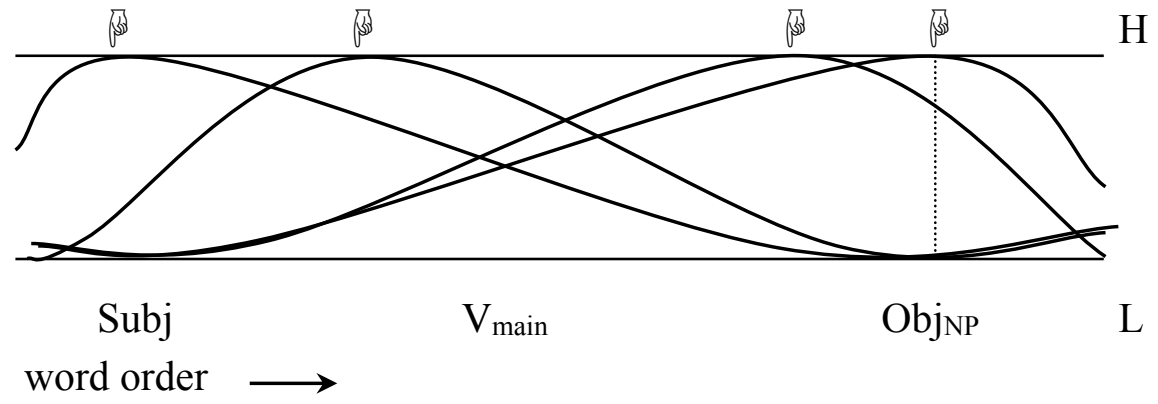

With this system, I firstly account for the facts on OS. Unmarked cases are illustrated in (14a). ${ }^{14}$ The fp is located on the sentence-final (full NP) object, on which the focal $\mathrm{H}$ also occurs. The intonation pattern is unmarked, since the pitch rises towards the object. The word order is not affected either. Examples are given in (14b).

a. Unmarked cases:

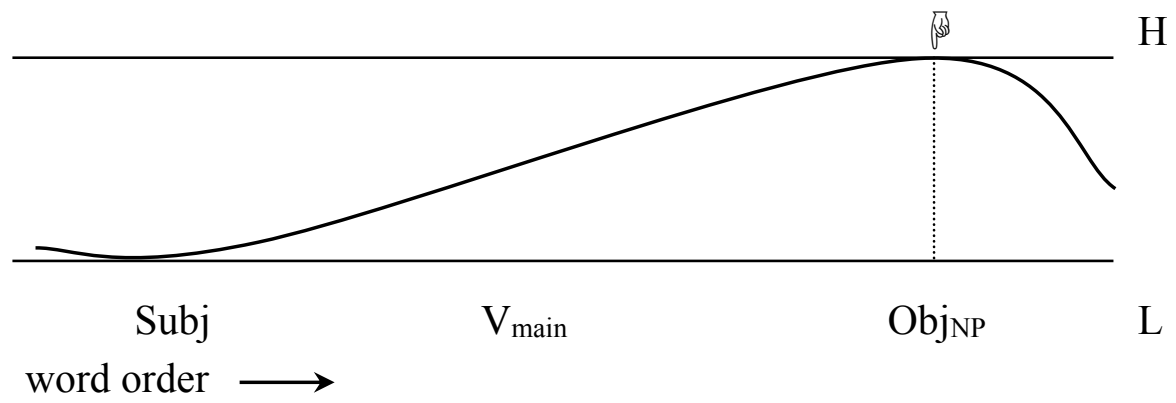

b. Jag kysste Anna. ${ }^{15}$ 'I kissed Anna.'

Jag har sett filmen. 'I have seen the movie.'

[Swe.]

Jag sa att jag kysste Anna. 'I said that I kissed Anna.'

In the non-OS construction such as complex tense forms and embedded clauses (15a), the fp moves from the object position to a past participle/embedded main verb which normally remains in situ. The intonation pattern is still unmarked, as downstep does not occur before that main verb. The word order is not affected either. Some examples are given in (15b).

14 This case includes that of a focused object pronoun in situ.

15 The locus of the (information/contrastive) focus of a sentence is indicated by italics. 




b. Jag har sett den./Jag har inte sett den.

[Swe.]

'I have seen it/I have not seen it.'

Jag sa att jag kysste henne./Jag sa att jag inte kysste henne.

'I said that I kissed her/I said that I didn't kiss her.'

In the OS construction such as simple tense forms (16a), however, the fp moves from the object position to the second position (and even to sentence-initial position in the case of Verb Topicalization). The intonation pattern is marked, since the pitch peak occurs on the main verb and downstep starts immediately after it. The word order is also affected, as illustrated by the presence of OS, in addition to verb movement. Examples are given in (16b). ${ }^{16}$

a. The OS construction:

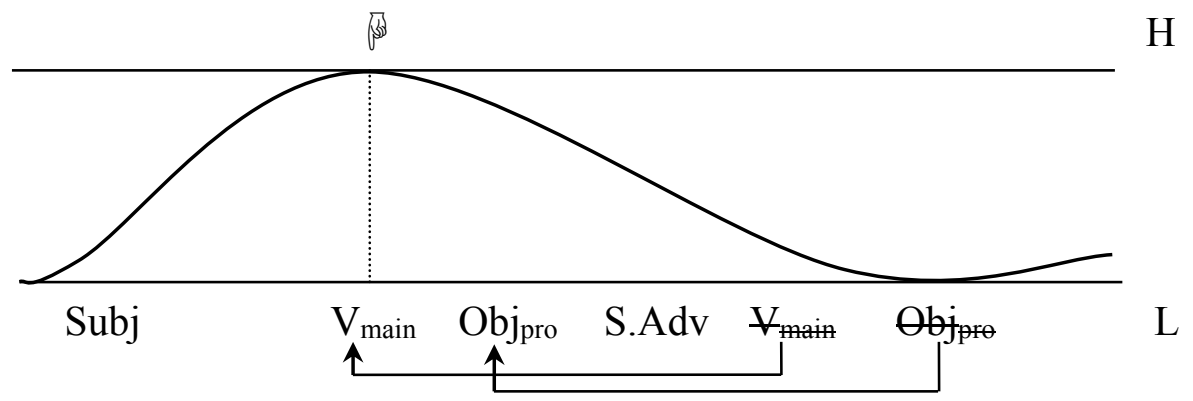

word order $\longrightarrow$

16 See Hosono (2013) for a hypothesis on Scandinavian OS: the object pronoun moves to cause downstep. With that hypothesis, Holmberg's Generalization is accounted for as follows. When main verb movement takes place, an object pronoun moves and causes downstep to eliminate a focal effect on the sentential element(s) after the main verb. In the environments in which downstep must not occur, i.e. in the constructions where the final pitch peak occurs on the (in-situ) main verb, OS does not occur either. Hosono also presents a new generalization on Scandinavian OS from the intonational perspective: the earlier the pitch gesture occurs, the more likely is OS to occur; the more delayed the pitch gesture is, the more likely is OS to be absent. It is argued that OS is a gradient phenomenon rather than a binary/dichotomous property in the Scandinavian languages. See Hosono for a thorough investigation of the intonational properties of Scandinavian OS. 
b. Jag kysste henne inte. 'I didn't kiss her.'

[Swe.]

Jag köpte den inte. 'I didn't buy it.'

Kysst har jag henne inte. 'I didn't KISS her.'

Here, I also account for focalization of object arguments in English; see (17). The fp moves from the object position to sentence-initial position. The intonation pattern is marked: downstep occurs immediately after the focal point in sentence-initial position. The word order is also likely to be affected, as illustrated by the presence of $w h$-movement (17a) and focus fronting (17b).

a. What did you do yesterday?

b. THAT ARTICLE, I didn't read today.

c.

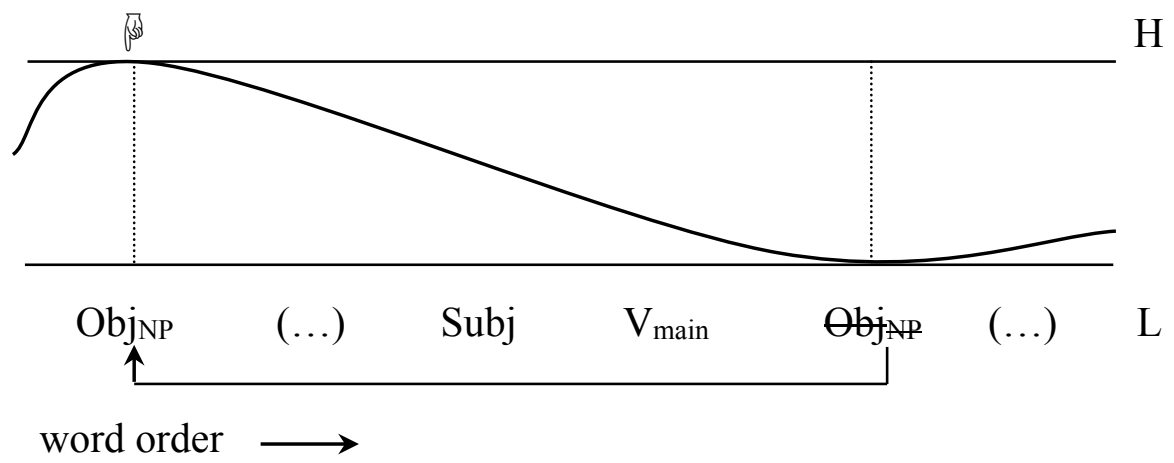

Example (18) is an illustration of the unmarked case of SOV languages. The syntactic word order is SOV from the left to the right. Since the focus is carried by a (full NP) object in the unmarked case, the fp is normally located on it. The pitch rises towards the object; the pitch peak occurs on one of the phrasal elements that compose the object. After that pitch peak, downstep occurs in the position(s) following that focal point.

The unmarked case of SOV languages:

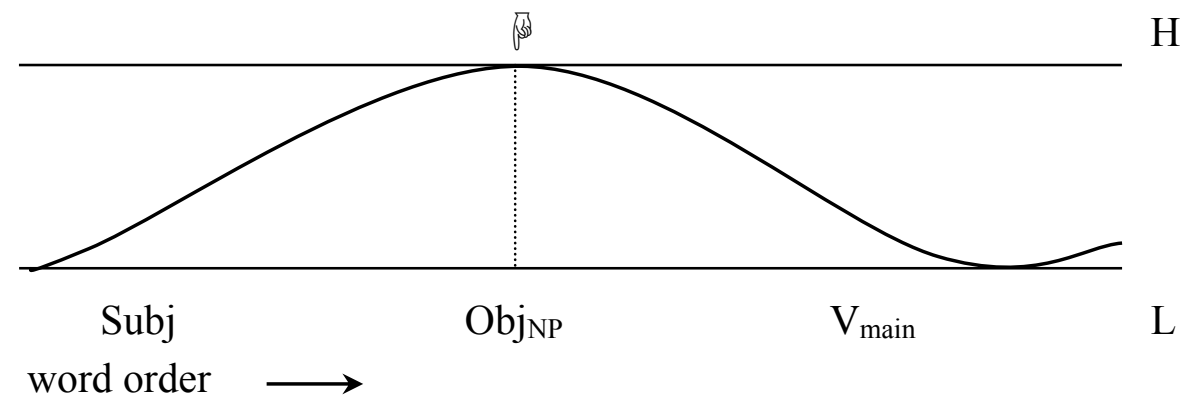

In this language type, the focus of a sentence and the final pitch peak occur on the position immediately preceding a verb. The prediction is that the farther the fp moves from the unmarked object position either to the left or to the right, the more the unmarked intonation 
pattern is likely to change, and the more the unmarked word order is likely to be affected too. The interaction between the changes of the focal point, the pitch peak point and the syntactic word order in SOV languages is illustrated in (19).

(19) The interaction between the changes of the focal point, the pitch peak point and the syntactic word order in SOV languages:

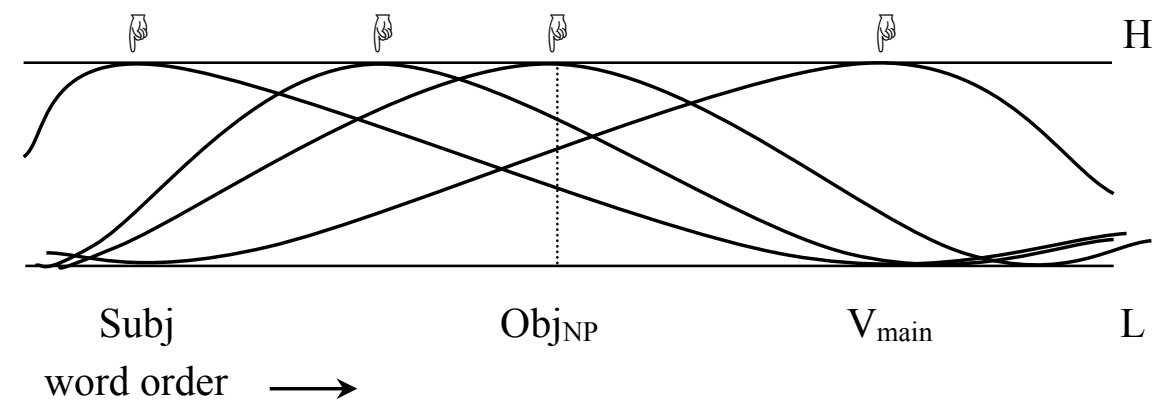

The prediction is confirmed by verb-focus and subject-focus in Japanese. In verb-focus (20a), the fp moves to the left of the object position. The intonation pattern is marked, since the pitch peak occurs on that focal point and downstep occurs immediately after it. The word order is affected too, as illustrated by the presence of verb fronting. In subject-focus (20b), the fp moves to the right of the object (, even across the main verb). The intonation pattern is marked, as downstep does not occur up to the focal point in sentence-final position. The word order is also affected as illustrated by the presence of subject postposing.

(20) a. watashi TABE-MASHI-TA ano keiki (totteoka-zuni).

I eat-HON-PAST that cake (keep-without)

'I ATE that cake (, not kept it).'

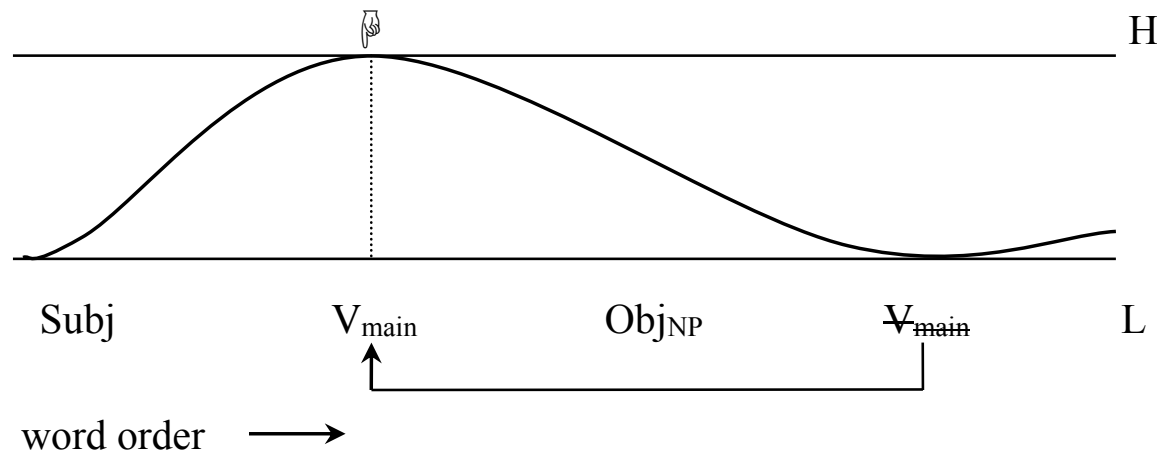

b. keiki-o kat-ta-no-wa WATASHI-desu (, haha-de-naku). cake-ACC buy-PAST-GEN-TOP I-be mother-be-not 'I bought the cake/It's ME who bought the cake (, not (my) mother).' 


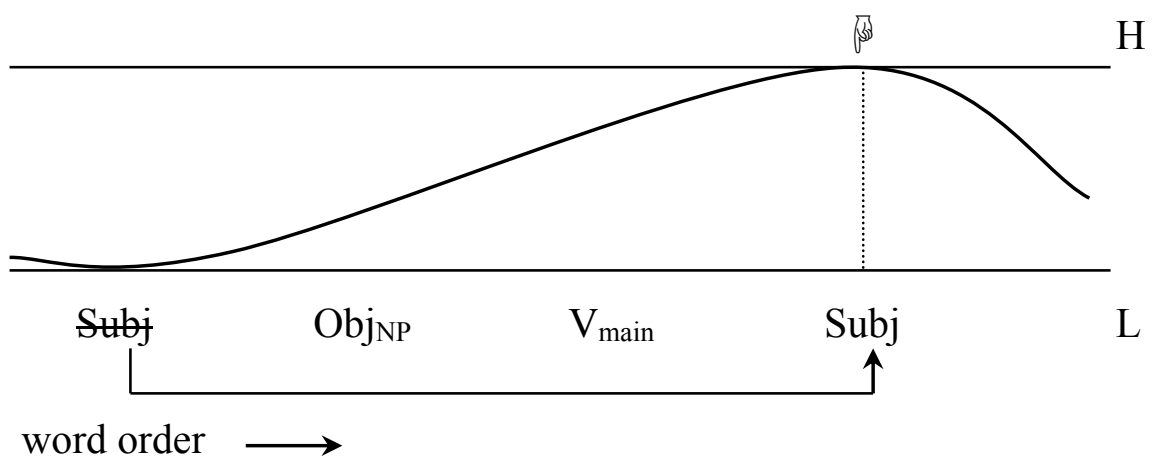

We find some cross-linguistic patterns. The first case is that the fp and the pitch peak move, but the word order is not affected. This case is illustrated by subject-focus in English; see (21). The fp moves from the object position to sentence-initial position. The intonation pattern is marked: downstep occurs immediate after that focal point. The word order, however, is not affected, as shown by the absence of movement.

\section{a. $\operatorname{JOHN}($, not Mary,) likes it.}

b.

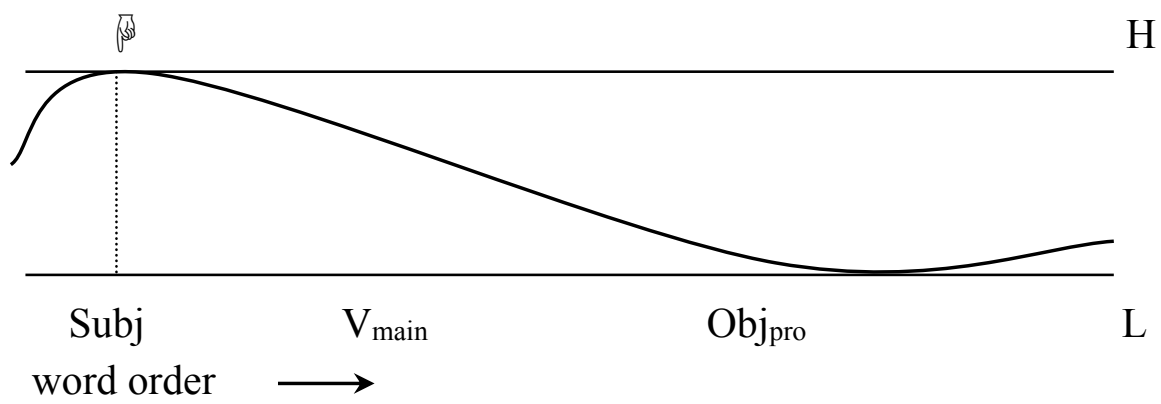

The second case is that the fp and the pitch peak do not move, but the word order is affected. This case is illustrated by scrambling in German (22). In broad-focus (22a), the fp is located on the position that immediately precedes the (past participle) main verb. The intonation pattern is unmarked, since the pitch peak occurs on the immediately preverbal focal point. The word order is also not affected. In contrastive argument-focus (22b) too, the fp is located on the position that immediately precedes the main verb. The intonation pattern is unmarked too, as the pitch rises to the immediately preverbal focal point. The word order, however, is affected as illustrated by movement of the direct object das Buch due to its given status.

a. Hans hat dem Kind das BUCH gegeben.

[Ger.]

Hans-NOM has the-DAT child the-ACC book given

'Hans gave the child the book.' 
b. Hans hat das Buch dem KIND gegeben.

Hans-NOM has the-ACC book the-DAT child given

'Hans gave the book to the CHILD (, not to her MOTHER).'

c.

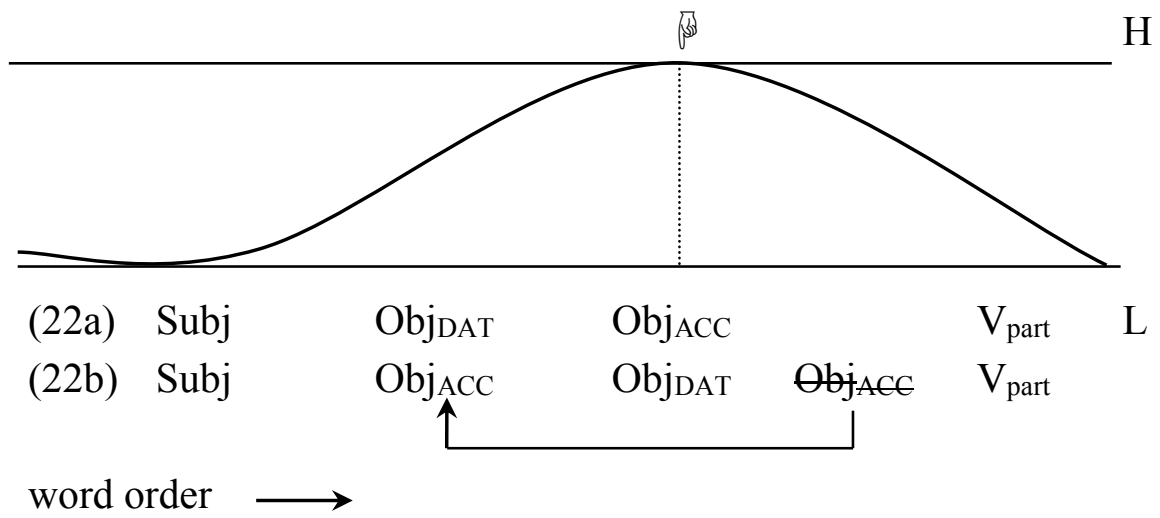

Finally, I mention individual cases in some languages. French is an SVO language that does not allow a preverbal focus; thus, it often employs the 'cleft construction' strategy (Lambrecht 2001). In broad-focus (23a), the fp is located on the (full NP) object. The intonation pattern is unmarked, since the pitch peak occurs on that sentence-final object position. The word order is also not affected. In subject-focus, the fp moves to the left of the object position, but it cannot occur on the preverbal subject in sentence-initial position: *JEAN l'aime (JEAN it likes 'JEAN likes it/It's JEAN who likes it'). Therefore, the word order is affected, and the sentence form is totally changed to a cleft construction as illustrated in (23b). The intonation pattern is also marked, as downstep occurs immediately after the focal point, i.e. the subject JEAN, which appears after the Aux.

a. Broad-focus:

Jean aime Marie.

Jean likes Marie

'Jean likes Marie.'

[Fre.]

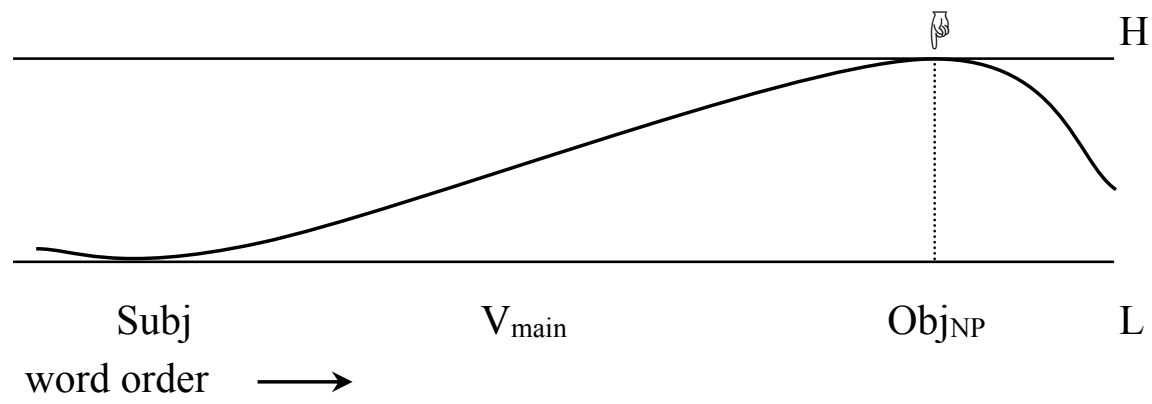


b. Subject-focus:

C'est JEAN qui l'aime.

it's Jean who it likes

'It is JEAN who likes it./JEAN likes it.'

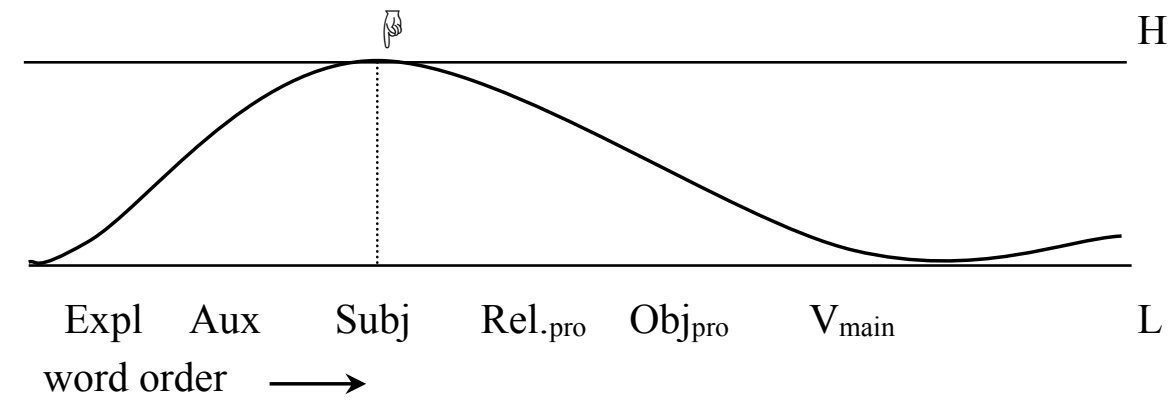

Hungarian is an SVO language that has different positions of a focal accent between broad-focus and (object) argument-focus, contrary to the so-called 'focus-projection' languages such as English (Halliday 1967, Chomsky 1970, Selkirk 1995). In Hungarian, the focal accent occurs on the main verb in broad-focus but occurs on the immediately preverbal position in (object) argument-focus (and in all other contexts) (Szendröi 2003). Specifically, in broad-focus (24a), the fp is located on the main verb kinézett. The intonation pattern is unmarked, since the pitch peak occurs on that main verb too. The word order is also not affected. In argument-focus (and in other contexts in general) (24b), the fp moves to the immediately preverbal position. The intonation pattern is marked, since the pitch peak occurs on that immediately preverbal focal point. The word order is also likely to be affected: a focused sentential element, i.e. the direct object kalapot here, moves to the immediately preverbal position.

a. Broad-focus:

Mari KINÉZETT magának egy kalapot.

Mari PRT-spotted herself-DAT a hat-ACC

[Hun.]

'(What did Mary do?) Mari chose a hat for herself.'



b. Other contexts:

Mari egy KALAPOT nézett ki.

Mari a hat-ACC spotted PRT

'(What did Mari choose?) Mari chose a hat.'

(Szendrői 2003:72-73, (57-58)) 


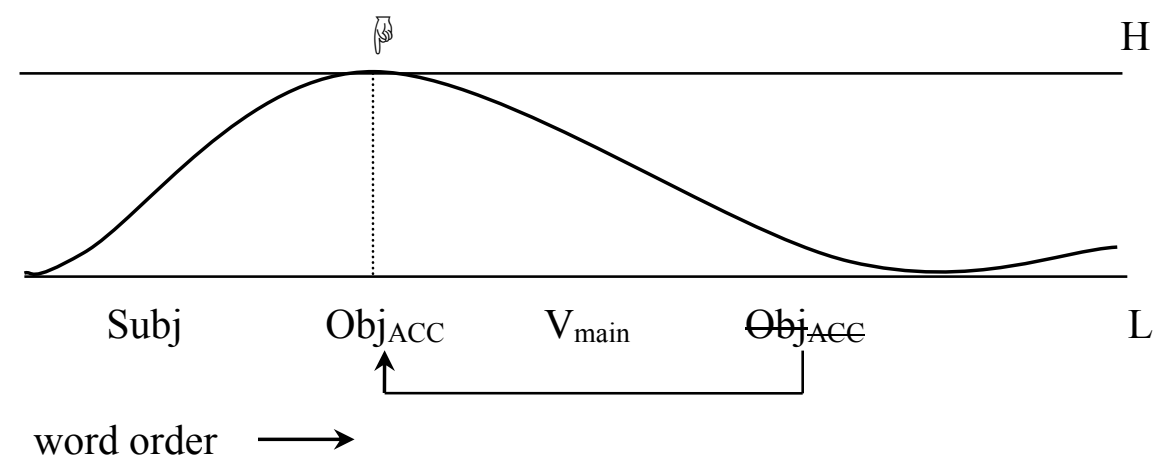

\section{Conclusions}

In this paper, I have showed that in the Scandinavian languages, the OS construction has intonational properties different from the non-OS construction: downstep occurs in the former but does not occur in the latter. This fact is confirmed by the statistical data that was analyzed on the basis of the experimental data collected from almost all the Scandinavian varieties investigated. I have then presented a new system that accounts for not only the facts on OS but also the interaction between the grammatical components in general. The basic idea is that in theorizing the interaction between syntax, phonology and information structure, only the focal point and the highest pitch peak point need to be taken into account. The proposed system has the fp, w, which is the indicator of the change in the information flow of a sentence. When it moves, the pitch peak moves too. A cross-linguistic prediction from this system is that the farther the fp moves from an unmarked position, the more an unmarked intonation pattern is likely to change, and the more an unmarked syntactic word order is likely to be affected. This prediction is confirmed by many linguistic facts observed in various languages.

\section{$6 \quad$ References}

Árnason, Kristján. 1999. Icelandic and Faroese. In Harry van der Hulst, eds., Word Prosodic Systems in the Languages of Europe, pp.567-591. Berlin: Mouton de Gruyter.

Árnason, Kristján. 2011. The Phonology of Icelandic and Faroese. Oxford: Oxford University Press.

Basbøll, Hans. 2005. The Phonology of Danish. Oxford: Oxford University Press.

Bresnan, Joan. 2001. Lexical-Functional Syntax. London: Blackwell.

Broekhuis, Hans. 2008. Derivations and Evaluations: Object Shift in the Germanic Languages. Berlin: Mouton de Gruyter.

Bruce, Gösta. 1977. Swedish Word Accents in Sentence Perspective. Travaux de L'Institut de Linguistique de Lund XII. CWK GLEERUP.

Bruce, Gösta. 1999. Word tone in Scandinavian languages. In Harry van der Hulst, eds., Word Prosodic Systems in the Languages of Europe, pp.605-633. Berlin: Mouton de Gruyter. 
Bruce, Gösta. 2005. Intonational Prominence in Varieties of Swedish Revisited. In Sun-Ah Jun, eds., Prosodic Typology: The Phonology of Intonation and Phrasing, pp.410-429. Oxford: Oxford University Press.

Bruce, Gösta. 2007. Components of a prosodic typology of Swedish intonation. In Tomas Riad and Carlos Gussenhoven, eds., Tones and Tunes Volume 1: Typological Studies in Word and Sentence Prosody, pp.113-146. Berlin: Mouton de Gruyter.

Bruce, Gösta and Eva Gårding. 1978. A Prosodic Typology for Swedish Dialects. In Eva Gårding, Gösta Bruce, and Robert Bannert, eds., Nordic Prosody, pp.219-228. Department of Linguistics, Lund University.

Chafe, Wallace. 1976. Givenness, contrastiveness, definiteness, subjects, topics and point of view. In Charles Li, eds., Subject and Topic, pp.25-56. New York: Academic Press.

Chomsky, Noam. 1970. Deep structure, surface structure, and semantic interpretation. In Noam Chomsky (1972), Studies on Semantics in Generative Grammar, pp.62-119. The Hague: Mouton.

Chomsky, Noam. 2001. Derivation by Phase. In Michael Kenstowicz, eds., Ken Hale: A Life in Language, pp.1-52. Cambridge, MA: MIT Press.

Chomsky, Noam and Morris Halle. 1968. The Sound Pattern of English. Cambridge, MA: MIT Press.

Cinque, Guglielmo. 1993. A null theory of phrase and compound stress. Linguistic Inquiry 24:239-297.

Dehé, Nicole. 2010. The timing of nuclear and prenuclear Icelandic pitch accents. Proceedings from Speech Prosody 2010, http://speechprosody2010.illinois.edu/papers/100009.pdf.

Diesing, Molly. 1992. Indefinites. Cambridge, MA: MIT Press.

Diesing, Molly. 1997. Yiddish VP Order and the Typology of Object Movement in Germanic. Natural Language and Linguistic Theory 15:369-427.

Dik, Simon C. 1978. Functional Grammar. Dordrecht: Foris Publications (third printing, 1981).

É. Kiss, Katalin. 1998. Identification Focus Versus Information Focus. Language 74:245-273.

Erteschik-Shir, Nomi. 2005a. Sound Patterns of Syntax: Object Shift. Theoretical Linguistics 31:47-93.

Erteschik-Shir, Nomi. 2005b. What is Syntax? Theoretical Linguistics 31:263-274.

Firbas, Jan. 1974. Some aspects the Czechoslovak approach to problems of functional sentence perspective. In Frantisek Daneš, eds., Papers on Functional Sentence Perspective, pp.11-37. The Hague: Mouton.

Fox, Danny and David Pesetsky. 2005. Cyclic Linearization of Syntactic Structure. Theoretical Linguistics 31:1-45.

Gårding, Eva. 1998. Intonation in Swedish. In Daniel Hirst and Albert Di Cristo, eds., Intonation Systems: A Survey of Twenty Languages, pp.112-130. Cambridge: Cambridge University Press. 
Givón, Talmy. 1979. From discourse to syntax: Grammar as a processing strategy. In Talmy Givón, eds., Syntax and Semantics 12: Discourse and Syntax, pp.81-111. New York: Academic Press.

Grønnum, Nina. 1998. Intonation in Danish. In Daniel Hirst and Albert Di Cristo, eds., Intonation Systems: A Survey of Twenty Languages, pp.131-151. Cambridge: Cambridge University Press.

Gundel, Jeanette K. 1974. The Role of Topic and Comment in Linguistic Theory. PhD dissertation, University of Texas, Austin.

Gundel, Jeanette K. 1988. Universals of topic-comment structure. In Michael Hammond, Edith Moravcsik, and Jessica Wirth, eds., Studies in Syntactic Typology, pp.209-239. Amsterdam: John Benjamins Publishing Company.

Gussenhoven, Carlos. 1984. On the Grammar and Semantics of Sentence Accents. Dordrecht: Foris Publications.

Gussenhoven, Carlos. 2004. The Phonology of Tone and Intonation. Cambridge: Cambridge University Press.

Gussmann, Edmund. 2002. Phonology: Analysis and Theory. Cambridge: Cambridge University Press.

Halliday, Michael A. K. 1967. Notes on Transitivity and Theme in English, Part II. Journal of Linguistics 3:199-244.

Hengeveld, Kees and J. Lachlan Mackenzie. 2006. Functional discourse grammar. In Bernd Heine and Heiko Narrog, eds., The Oxford Handbook of Linguistic Analysis, pp.367-400. Oxford: Oxford University Press.

Holmberg, Anders. 1986. Word Order and Syntactic Features in the Scandinavian Languages and English. $\mathrm{PhD}$ dissertation, University of Stockholm.

Holmberg, Anders. 1999. Remarks on Holmberg's Generalization. Studia Linguistica 53:1-39.

Holmberg, Anders and Christer Platzack. 1995. The Role of Inflection in Scandinavian Syntax. Oxford: Oxford University Press.

Hosono, Mayumi. 2013. Object Shift in the Scandinavian Languages: Syntax, Information Structure, and Intonation. $\mathrm{PhD}$ dissertation, Leiden University.

Jackendoff, Ray. 1972. Semantic Interpretation in Generative Grammar. Cambridge, MA: MIT Press.

Josefsson, Gunlög. 2003. Four Myths about Object Shift in Swedish - and the Truth.... In Lars-Olof Delsing, Cecilia Falk, Gunlög Josefsson, and Halldór Á. Sigurðsson, eds., Grammar in Focus: Festschrift for Christer Platzack 18 November 2003 Volume 1, pp.199-207. Department of Scandinavian Languages, Lund University.

Kahnemuyipour, Arsalan. 2009. The Syntax of Sentential Stress. Oxford: Oxford University Press. Kristoffersen, Gjert. 2000. The Phonology of Norwegian. Oxford: Oxford University Press.

Kristoffersen, Gjert. 2007. Dialect variation in East Norwegian tone. In Tomas Riad and Carlos Gussenhoven, eds., Tones and Tunes Volume 1: Typological Studies in Word and Sentence 
Prosody, pp.91-111. Berlin: Mouton de Gruyter.

Kristoffersen, Gjert. 2008. Level stress in North Germanic. Journal of Germanic Linguistics 20:87-157.

Kuno, Susumu. 1976. Subject, Theme and the Speaker's Empathy: A Reexamination of Relativization Phenomena. In Charles Li, eds., Subject and Topic, pp.417-444. New York: Academic Press.

Lambrecht, Knud. 1994. Information Structure and Sentence Form: Topic, Focus, and the Mental Representations of Discourse Referents. Cambridge: Cambridge University Press.

Lambrecht, Knud. 2001. A Framework for the Analysis of Cleft Constructions. Linguistics 39:463-516.

Li, Charles and Sandra A. Thompson. 1976. Subject and topic: a new typology of language. In Charles Li, eds., Subject and Topic, pp.457-490. New York: Academic Press.

Mathesius, Vilém. 1929. Functional linguistics. In Josef Vachek, and Libuše Dušková, eds., Praguiana, pp.121-142. Amsterdam: John Benjamins.

Mikkelsen, Line. 2011. On Prosody and Focus in Object Shift. Syntax 14:230-264.

Rietveld, Antonie C.M. and Vincent J. van Heuven. 2009. Algemene Fonetiek [General Phonetics]. Bussum: Coutinho.

Rizzi, Luigi. 1997. The Fine Structure of the Left Periphery. In Liliane Haegeman, eds., Elements of Grammar, pp.281-338. Dordrecht: Kluwer.

Rochemont, Michael S. 1986. Focus in Generative Grammar. Amsterdam: John Benjamins Publishing Company.

Schmerling, Susan F. 1976. Aspects of English Sentence Stress. Austin: University of Texas Press.

Schwabe, Kerstin and Susanne Winkler. (eds.) 2007. On Information Structure, Meaning, and Form: Generalization Across Languages. Amsterdam: John Benjamins Publishing Company.

Selkirk, Elisabeth O. 1984. Phonology and Syntax: The Relation between Sound and Structure. Cambridge, MA: MIT Press.

Selkirk, Elisabeth. 1995. Sentence prosody: Intonation, stress, and phrasing. In John A. Goldsmith, eds., The Handbook of Phonological Theory, pp.550-569. London: Blackwell.

Sells, Peter. 2001. Structure, Alignment and Optimality in Swedish. Stanford, CA: CSLI Publications.

Steube, Anita. (eds.) 2004. Information Structure. Berlin: Walter de Gruyter.

Szendröi, Kriszta. 2003. A Stress-Based Approach to the Syntax of Hungarian Focus. The Linguistic Review 20:37-78.

't Hart, Johan, René Collier, and Antonie Cohen. 1990. A Perceptual Study of Intonation. Cambridge: Cambridge University Press.

Vallduví, Enric. 1990. Information Structure and the Scope of Sentential Negation. In Kira Hall, Jean-Pierre Koenig, Michael Meacham, Sondra Reinman, and Laurel A. Sutton, eds., Proceedings of the Sixteenth Annual Meeting of the Berkeley Linguistics Society, 
pp.325-337. Berkeley Linguistics Society.

Vallduví, Enric and Elisabet Engdahl. 1996. The Linguistic Realization of Information Packaging. Linguistics 34:459-519.

Vikner, Sten. 2001. The Interpretation of Object Shift and Optimality Theory. In Gereon Müller and Wolfgang Sternefeld, eds., Competition in Syntax, pp.321-340. Berlin: Mouton de Gruyter.

Vilkuna, Maria. 1995. Discourse Configurationality in Finnish. In Katalin É. Kiss, eds., Discourse Configurational Languages, pp.244-268. Oxford: Oxford University Press.

Zubizarreta, Maria Luisa. 1998. Prosody, Focus, and Word Order. Cambridge, MA: MIT Press. 


\section{$7 \quad$ Appendix: Test sentences for Swedish informants}

A. Målade du väggen? - Nej, jag målade den inte. painted you the-wall no I painted it not 'Did you paint the wall? - No, I didn't paint it.'

B. Målade du Jan?-Nej, jag målade honom inte. portrayed you Jan no I portrayed him not 'Did you portray Jan? - No, I didn't portray him.'

C. Har du målat Jan? have you portrayed Jan 'Have you portrayed Jan?'

- Målat har jag honom inte. Men jag har tagit foto av honom. portayed have I him not but I have taken photos of him '- I haven't PORTRAYED him. But I have taken photos of him.'

D. Har du målat väggen? - Nej, jag har inte målat den. have you painted the-wall no I have not painted it 'Have you painted the wall? - No, I haven't painted it.'

E. Har du målat Jan? - Nej, jag har inte målat honom. have you portrayed Jan no I have not portrayed him 'Have you portrayed Jan? - No, I haven’t portrayed him.'

F. Målade du Jan? - Nej, jag målade inte HONOM. Men jag målade Mats. portrayed you Jan no I portrayed not him but I portrayed Mats 'Did you portray Jan? - No, I didn't portray HIM. But I portrayed Mats.'

G. Vad sa du? - Jag sa att jag inte målade honom. what said you I said that I not portrayed him 'What did you say? - I said that I didn't portray him.' 